\title{
Development of Instant Dokla Mix Blended with Dehydrated Carrot Powder
}

\author{
A. Priya ${ }^{1}$, R. Rosalin Nikitha ${ }^{2}$ \\ ${ }^{1}$ Assistant Professor, Department of Foods and Nutrition, Rathnavel Subramaniam College of Arts and Science, Sulur, \\ Coimbatore 6410402. \\ ${ }^{2}$ II M.Sc Foods and Nutrition \& Rathnavel Subramaniam College of Arts and Science, Sulur, Coimbatore 6410402.
}

\begin{abstract}
This study presents the Development of Instant Dhokla mix blended with dehydrated carrot powder. Dhokla is a vegetarian food originating from Gujarat, India. It can be eaten for breakfast, as a main course, as a side dish or as a snack and is usually tangy and slightly sweet in taste. Carrot is one of the nutritious and economical vegetable. To extend carrot's utilization during offseason, carrot was oven-dried at $50^{\circ} \mathrm{C}$ for $4-5$ hours and powdered. The Dehydrated carrot (Daucus carota L.) powder was blended at the levels of $10 \%, 20 \%, 30 \%$ and $40 \%$ in the Instant Dhokla mix powder. The best variation was identified to be the Sample C in which 30\% Dehydrated carrot powder was blended in Instant Dhokla mix. It was identified by sensory analysis using five point hedonic scale by a group of 30 semi trained panel members. Vitamin A content was $5.4 \mathrm{mcg} / 100 \mathrm{~g}$ in the standard instant Dhokla mix which increased to $9.2 \mathrm{mcg} / 100 \mathrm{~g}$ in the Sample C and Iron content was $3.5 \mathrm{mg} / 100 \mathrm{~g}$ in the standard instant Dhokla mix which increased to $6.0 \mathrm{mg} / 100 \mathrm{~g}$ in the Sample C. The mix underwent microbial analysis and shelf life analysis with the interval of one day for a period of one week that is on $1^{\text {st }}$ day, $3^{\text {rd }}$ day and $5^{\text {th }}$ day respectively. The mix was stored in a Zip lock bag. The popularization of the Instant Dhokla mix blended with dehydrated carrot powder was done among school going children by briefing on its significance, functional properties, nutritional aspects and health benefits with the help of a questionnaire and analyzing their responses.
\end{abstract}

KEYWORDS: Dehydrated Carrot Powder, Iron, Instant Dhokla Mix, Sensory Analysis, Popularization, Shelf Life, Vitamin A.

\section{INTRODUCTION}

Food is a substance consisting essentially of protein, carbohydrate, fat, and other nutrients used in the body of an organism to sustain growth and vital processes and to furnish energy. New product development (NPD) is the process of designing a new product, producing it and bringing it to market. Product development is a continuously expanding list of research actions, involving issues connected with core product itself and issues concerning quality assurance, packaging, technical aspects of production, nutritional value labeling, raw materials, technology that needs to be used and marketing (Mcllveen, 1994).

Dhokla is a vegetarian food item that is made with a fermented batter derived from chickpea flour. Dhokla can be eaten for breakfast, as a main course, as a side dish or as a snack. It is usually tangy and slightly sweet in taste. It is usually liked by all age groups, as it has a soft texture therefore is suitable even for old people and children. (Amruta S. Lohekar and Asha B. Arya., 2014)

Carrot (Daucus carota L.) is a biennial herbaceous species which is a member of the Apiaceae family. The carrots are a good source of carotenoids, vitamins, and dietary fiber and is also rich in minerals and antioxidants. They are also rich in potassium, magnesium, calcium, sodium, and iron. (Feng Que et al., 2019). To extend carrot's utilization during off-season with maximum retention of $\beta$-carotene, oven-drying is a low-cost conventional method.. Hot-air drying methods could results in a quality product characterised by uniform, hygienic and attractive colour of dried fruit and vegetables powder (Roongruangsri W \& Bronlund J.E, 2016). Dried powdered carrot has been used in several items in Indian culinary and offers healthy alternative without much sacrificing in nutritive value.

Objectives of the study are as follows:

- To develop Instant Dhokla mix blended with Dehydrated Carrot powder.

- To evaluate the best proportions of the Dehydrated carrot powder in the Dhokla.

- To analyze the nutrient content of standard and selected best proportion of the dehydrated carrot powder blended Instant Dhokla mix.

- To determine the microbial analysis of the product. 


\section{International Journal of Current Science Research and Review}

ISSN: 2581-8341

Volume 05 Issue 02 February 2022

DOI: 10.47191/ijesrr/V5-i2-29, Impact Factor: 5.825

IJCSRR@ 2022

- To estimate cost of the prepared product.

- To popularize the product among School going children.

\section{MATERIALS AND METHODS}

1.1. Selection and Procurement of Ingredients: The ingredient selected is Dehydrated carrot powder which is blended in Instant Dhokla mix. The ingredients required for the preparation of the product were procured in the local market as it is convenient for the researcher.

1.2. Processing of Dehydrated Carrot powder

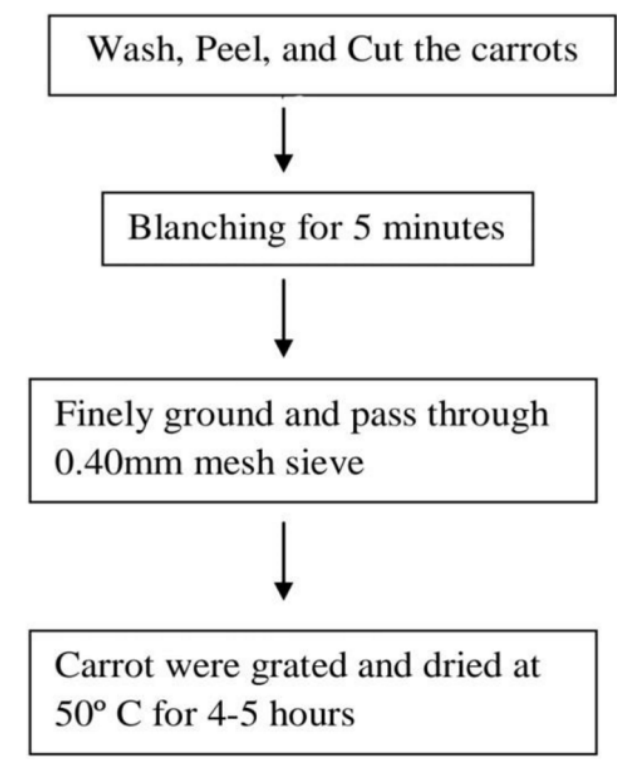

Figure 1 - Processing of Dehydrated carrot powder

\subsection{Preparation method of Standard Instant Dhokla mix and Dhokla}

$>\quad$ Add Bengal gram flour, $2-3$ pinches of turmeric, Citric acid crystals, baking powder and required amount of salt in a bowl.

Mix them well, make into a batter using water and allow it to rest for 15 minutes.

Grease a steaming pan with oil, pour the batter and steam it for 15 -20 minutes.

After it is cooked cut it into small pieces.

In a pan, add little oil, mustard seeds, curry leaves and Green chilies.

Sauté along with the pieces of Dhokla.

\subsection{Preparation of Dehydrated Carrot powder blended Instant Dhokla mix}

$>\quad$ Take Bengal gram flour (70 g), Dehydrated carrot powder (30 g), Turmeric powder (a pinch), Baking soda (1 g) and Citric acid crystals $(0.5 \mathrm{~g})$ and mix them all in a bowl.

$>\quad$ Pack it in a Zip lock bag under sterile condition and store it.

\subsection{Standardization and Sensory evaluation of the Product}

Standardization helps in ensuring the safety, interoperability, and compatibility of goods produced. The Carrot powder was incorporated at 10\%, 20\%, 30\% and 40\%. Sensory Evaluation has been defined as "A scientific discipline used to evoke, measure, analyze and interpret reactions to those properties of foods and materials as they are perceived by senses of sight, smell, taste, touch, and hearing" (Sidel \& Stone, 1993). It is performed using five point hedonic scale. 


\section{International Journal of Current Science Research and Review}

ISSN: 2581-8341

Volume 05 Issue 02 February 2022

DOI: 10.47191/ijcsrr/V5-i2-29, Impact Factor: 5.825

IJCSRR@ 2022

www.ijcsrr.org

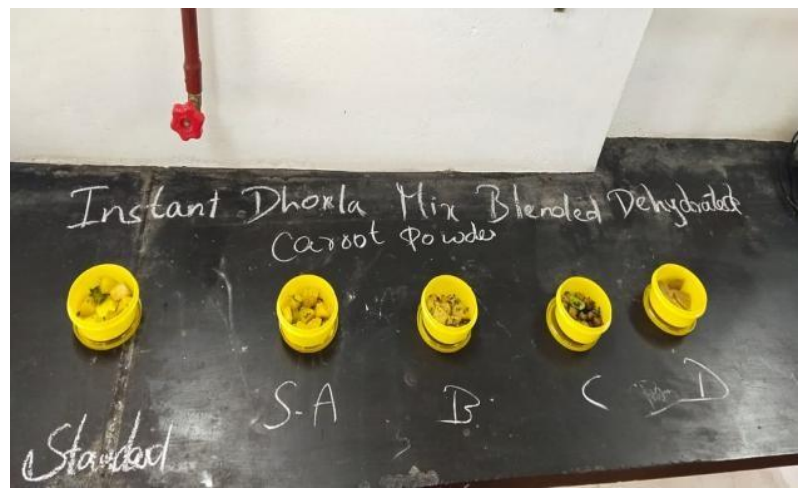

Figure 2 - Instant Dhokla mix blended with dehydrated carrot powder in different variations

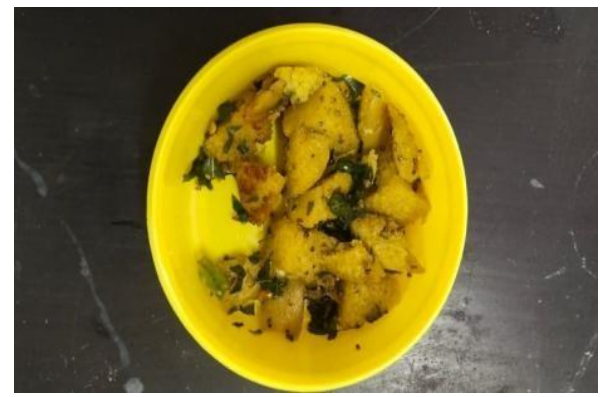

Figure 3 - Sample C selected as Best Variant

\subsection{Nutritional analysis}

Nutritional analysis is the process of determining the nutritional content of food. The standard and the best variant is analysed for the nutrients such as Vitamin a and Iron.

\subsection{Microbial analysis}

The microbial analysis was carried out at an interval of 1 day for a period of 1 week, that is on $1^{\text {st }}$ day, $3^{\text {rd }}$ day and $5^{\text {th }}$ day respectively.

\subsection{Cost analysis}

The primary reason for conducting cost analysis is generally to determine the true (full) costs of each of the programs under analysis (services and/or products). The cost estimation was done on the basis of cost of the ingredients used in the new product.

\subsection{Popularization}

The product, Instant Dhokla mix blended with dehydrated carrot powder is popularized among 30 School children, where the benefits of Dehydrated carrot powder and Dhokla were educated.

\section{RESULT AND DISCUSSION}

\subsection{Comparison of the Selected product with the Standard product}

Table - I depict the comparison of the sensory attributes of the selected Instant Dhokla mix with the standard product.

From the results it can be concluded that the Instant dhokla mix blended with dehydrated carrot powder had a good shelf life of upto 5 days under room temperature by the use of vacuum packaging - Ziplock bag. 


\section{International Journal of Current Science Research and Review}

ISSN: 2581-8341

Volume 05 Issue 02 February 2022

DOI: 10.47191/ijesrr/V5-i2-29, Impact Factor: 5.825

IJCSRR@ 2022

$\underline{\text { www.ijcsrr.org }}$

Table I. Comparision of the selected product with the Standard product

\begin{tabular}{|l|l|l|l|l|}
\hline S.no & Criteria & Score & Standard Product & Selected Product \\
\hline 1 & Appearance & 5 & $4.9 \pm 0.25$ & $4.9 \pm 0.3$ \\
\hline 2 & Colour & 5 & $4.9 \pm 0.3$ & $4.8 \pm 0.37$ \\
\hline 3 & Flavour & 5 & $4.9 \pm 0.3$ & $4.9 \pm 0.3$ \\
\hline 4 & Texture & 5 & $4.9 \pm 0.25$ & $4.9 \pm 0.34$ \\
\hline 5 & Taste & 5 & $4.96 \pm 0.18$ & $4.97 \pm 0.18$ \\
\hline
\end{tabular}

From the Table I it is clear that Sample C had the similar mean score in all the criteria to that of the Standard product. So Sample C was chosen as the best product and subjected to further analysis.

\subsection{Shelf life analysis of the Standard and Selected product}

The mean sensory scores of standard and Instant Dhokla mix blended with dehydrated carrot powder on storage are given in Table - II.

Table II. Sensory Analysis of the Standard and Selected Product

\begin{tabular}{|c|c|c|c|c|c|c|c|c|}
\hline \multirow[t]{2}{*}{ S.no } & \multirow[t]{2}{*}{ Criteria } & \multirow[t]{2}{*}{ Score } & \multicolumn{2}{|c|}{$\begin{array}{l}\text { Day-1 Mean } \pm \\
\text { SD }\end{array}$} & \multicolumn{2}{|c|}{$\begin{array}{l}\text { Day-3 Mean } \pm \\
\text { SD }\end{array}$} & \multicolumn{2}{|c|}{$\begin{array}{l}\text { Day-5 } \\
\text { Mean } \pm \text { SD }\end{array}$} \\
\hline & & & Standard & Sample & Standard & Sample & Standard & Sample \\
\hline 1 & Appearance & 5 & $4.9 \pm 0.25$ & $4.9 \pm 0.3$ & $4.9 \pm 0.3$ & $4.93 \pm 0.25$ & $4.8 \pm 0.4$ & $4.77 \pm 0.5$ \\
\hline 2 & Colour & 5 & $4.9 \pm 0.3$ & $4.8 \pm 0.37$ & $4.87 \pm 0.46$ & $4.83 \pm 0.45$ & $4.87 \pm 0.42$ & $4.83 \pm 0.37$ \\
\hline 3 & Flavour & 5 & $4.9 \pm 0.3$ & $4.9 \pm 0.3$ & $4.9 \pm 0.25$ & $4.96 \pm 0.18$ & $4.87 \pm 0.43$ & $4.9 \pm 0.3$ \\
\hline 4 & Texture & 5 & $4.9 \pm 0.25$ & $4.9 \pm 0.34$ & $4.9 \pm 0.3$ & $4.9 \pm 0.3$ & $4.93 \pm 0.25$ & $4.9 \pm 0.4$ \\
\hline 5 & Taste & 5 & $4.96 \pm 0.18$ & $4.97 \pm 0.18$ & $4.87 \pm 0.34$ & $4.83 \pm 0.37$ & $4.9 \pm 0.25$ & $4.9 \pm 0.3$ \\
\hline \multicolumn{3}{|c|}{ Over all acceptability } & $4.9 \pm 0.26$ & $4.89 \pm 0.3$ & $4.89 \pm 0.33$ & $4.89 \pm 0.31$ & $4.87 \pm 0.35$ & $4.87 \pm 0.37$ \\
\hline
\end{tabular}

\subsection{Nutrient analysis of the Standard and the Selected product}

Nutritional Analysis refers to the laboratory evaluation of the nutritional content of a food. The Vitamin A content was 5.4 mcg/100g in the standard instant Dhokla mix which increased to $9.2 \mathrm{mcg} / 100 \mathrm{~g}$ in the Sample C and Iron content was $3.5 \mathrm{mg} / 100 \mathrm{~g}$ in the standard instant Dhokla mix which increased to $6.0 \mathrm{mg} / 100 \mathrm{~g}$ in the Sample C.

\subsection{Microbial analysis of the Standard and Selected product}

The details regarding the microbial content in standard Instant Dhokla mix and selected proportion that is sample $\mathrm{C}$ which is a Dehydrated carrot powder blended Instant Dhokla mix on storage is given In Table III. The microbial analysis was carried out in an interval of 1 day for a period of 1 week, that is on $1^{\text {st }}$ day, $3^{\text {rd }}$ day and $5^{\text {th }}$ day. 


\section{International Journal of Current Science Research and Review}

ISSN: 2581-8341

Volume 05 Issue 02 February 2022

DOI: 10.47191/ijesrr/V5-i2-29, Impact Factor: 5.825

IJCSRR@ 2022

Table III. Microbial Analysis of the Standard Product and Selected Product

\begin{tabular}{|c|c|c|c|c|}
\hline \multirow[t]{2}{*}{ S.no } & \multirow{2}{*}{$\begin{array}{l}\text { Name of the } \\
\text { sample }\end{array}$} & \multicolumn{3}{|c|}{ Total plate count } \\
\hline & & $1^{\text {st }}$ day & $3^{\text {rd day }}$ & $5^{\text {th }}$ day \\
\hline 1. & Standard & $21 \times 10^{1} \mathrm{cfu} / \mathrm{g}$ & $24 \times 10^{1} \mathrm{cfu} / \mathrm{g}$ & $26 \times 10^{1} \mathrm{cfu} / \mathrm{g}$ \\
\hline 2. & Sample & $22 \times 10^{1} \mathrm{cfu} / \mathrm{g}$ & $23 \times 10^{1} \mathrm{cfu} / \mathrm{g}$ & $25 \times 10^{1} \mathrm{cfu} / \mathrm{g}$ \\
\hline
\end{tabular}

For Instant mixes $<10^{4} \mathrm{cfu} / \mathrm{g}$ is considered as Satisfactory, whereas $<10^{5}$ and $\geq 10^{5}$ are considered as Marginal and Unsatisfactory. So it can be concluded that the result is Satisfactory and safe to consume as the result for both standard and sample for the $1^{\text {st }}$ day, $3^{\text {rd }}$ day and $5^{\text {th }}$ day shows $<10^{4} \mathrm{cfu} / \mathrm{g}$ and the number of conies can be reduced if properly stored.

\subsection{Cost estimation of the Standard and Selected product}

The cost of standard Instant Dhokla mix is Rs. 22.34 /- per 100g and the cost of Instant Dhokla mix blended with Dehydrated carrot powder is Rs. 21.78 /- per 100g and this was compared with standard, there is a decrease in the cost of Instant Dhokla mix blended with Dehydrated carrot powder.

\subsection{Popularization of the Selected product}

Popularization mainly focuses on creating awareness among the public about the beneficial effects of a newly formulated food product. The popularization of the Instant Dhokla mix blended with dehydrated carrot powder was done among School going children by briefing on its significance, functional properties, nutritional aspects and health benefits with the help of a questionnaire. The results shows that the school going children are interested in consuming carrot whereas $40 \%$ are not interested; $73 \%$ school going children are aware that Vitamin A plays a major role in vision process whereas $27 \%$ are not aware of it; $33 \%$ school going children knows that the deficiency of Vitamin A can cause Night Blindness whereas $67 \%$ didn't know this; $53 \%$ of school going children have had Dhokla before whereas $47 \%$ were having Dhokla for the first time; $40 \%$ of the school going children have already tried Instant

Dhokla mix from the market, whereas $60 \%$ haven't; $57 \%$ school going children were aware that carrots are rich in Vitamin A whereas $43 \%$ were unaware of it; 53\% school going children knew that iron deficiency leads to Anemia whereas 47\% didn't know it; $13 \%$ school going children knew about the dehydrated carrot powder whereas $87 \%$ didn't know about it; $90 \%$ school going children liked the product and $10 \%$ of them didn't like it; $87 \%$ of school going children have shown interest to buy this product if it is available in the market and $13 \%$ have not shown much interest.

\section{CONCLUSION}

From the study, it is concluded that the Instant Dhokla mix blended with Dehydrated carrot powder, which has $30 \%$ of Dehydrated carrot powder was accepted in studies. The prepared product is high in Vitamin A and Iron when compared to the standard product. The prepared product is acceptable till $5^{\text {th }}$ day without any microbial deterioration if it is stored in Zip lock bag at room temperature. The cost of the prepared best product was slightly lower than standard. In the popularization study most of the participants accepted the product.

\section{ACKNOWLEDGEMENT}

I express my sincere gratitude to the Panel members who helped with the Sensory evaluation.

\section{REFERENCES}

1. Mcllveen H. (1994) Product Development and the Consumer: The Reality of Managing Creativity. Nutrition \&amp; Science No. 6.

2. Amruta S. Lohekar and Asha B. Arya., 2014., Development of value added instant 'dhokla' mix., (C) 2012 IJFANS , Vol.3, Iss.4,.pg $78-83$. 


\section{International Journal of Current Science Research and Review}

ISSN: 2581-8341

Volume 05 Issue 02 February 2022

DOI: 10.47191/ijesrr/V5-i2-29, Impact Factor: 5.825

IJCSRR@ 2022

3. Feng Que, Xi-Lin Hou, Guang-Long Wang, Zhi-Sheng Xu, Guo-Fei Tan, Tong Li, Ya-Hui Wang, Ahmed Khadr and Ai-Sheng Xiong ., 01 June 2019 , Advances in research on the carrot, an important root vegetable in the Apiaceae family, Horticulture Research volume 6, Article number: 69.

4. Roongruangsri, W. and Bronlund, J. E. (2016). Effect of air-drying temperature on physic - chemical, powder properties and sorption characteristics of pumpkin powders, International Food Research Journal 23(3), 962-972.

5. Sidel, J.L., \& Stone, H. (1993). The role of sensory evaluation in the food industry. Food Quality \& Preference, 4, 65-73. San Diego: Academic Press.

Cite this Article: A. Priya, R. Rosalin Nikitha (2022). Development of Instant Dokla Mix Blended with Dehydrated Carrot Powder. International Journal of Current Science Research and Review, 5(2), 547-552 